\title{
Case Report - Adenosine: A Cause of Angina
}

\author{
Jadhav Ajit ${ }^{1 *}$ and Hardas Suhas ${ }^{2}$ \\ ${ }^{1}$ Interventional Cardiologist, Baroda heart Institute and research Centre, India \\ ${ }^{2}$ Department of cardiology, Poona Hospital and Research Centre, India
}

Submission: September 06, 2018; Published: October 09, 2018

*Corresponding author: Jadhav Ajit, Interventional Cardiologist, Baroda heart Institute and research Centre, 102, Wingsville appt. 41 Arunodaya Society, Alkapuri, Vadodara, Gujarat, India 390007, Tel: +91-9028898494; Email: ajit92698@gmail.com

\begin{abstract}
Adenosine has a critical role in the non-invasive and invasive assessment of myocardial perfusion as well as having therapeutic efficacy in patients with no-reflow. It has an important role in both the diagnosis and treatment of a range of arrhythmias. Although side effects are frequently reported, they are seldom troublesome and due to the short half-life of the drug, are transient. Commonly reported side effects included flushing, dyspnoea, chest pain, gastrointestinal discomfort, nausea, vomiting, headache, AV block and arrhythmias. We report one of our patients, while undergoing fractional flow reserve measurement for functional significance of the moderate epicardial coronary luminal narrowing (70\%) experienced similar angina what he used to experience while exertion. In Such clinical scenario, revascularization Vs deferral of such lesions can still be safely considered or not.
\end{abstract}

Keywords: Adenosine; Angina; FFR

\section{Introduction}

Adenosine is an extracellular signaling molecule with essential functions in human physiology. Due to the widespread expression of adenosine receptors, it has many effects across different organ systems. It has been extensively studied for both its therapeutic and diagnostic abilities due to its prominent role in cardiovascular system.

An important target of adenosine is the coronary microcirculation where adenosine acts as a prominent vasodilator with many of the beneficial effects of adenosine reflected in its capacity to affect the micro vessels and acts as a coronary hyperemic agent during vasodilator stress testing. Adenosine also has an important role in the pre-conditioned state and also in the attenuation of ischemia-reperfusion injury [1].

\section{Case Report}

57-year-old male, with family history of Ischemic heart disease, presented with typical exertional retrosternal squeezing type of chest pain radiating to jaw, lasting for a minute or two, which promptly used to relieve with rest. ECG showed T inversions in anterior precordial leads. He had two such episodes in the preceding month.

- $\quad$ Exercise stress test: was strongly positive at 7 METs with significant ST depressions at peak exercise as well as during recovery. He was subjected to coronary angiogram which revealed moderate $70 \%$ stenosis in the mid segment of the LAD. Rest of the arteries were normal. He was subjected to FFR evaluation for objective assessment of inducible ischemia in the LAD territory prior to decision of revascularisation.
- $\quad$ FFR: Was done with institutional study protocol and incremental doses IC Adenosine 150, 180 ug injections were given and FFR values were obtained. FFR in the lesion was noted to be 0.81 . However patient experienced similar chest heaviness and squeezing type of retrosternal pain after every injection of hyperaemic agent what he uses to experience prior.

Chest heaviness relieved on its own within 2-5 minutes and was not associated with any ST segment deviations on the ECG and sinus rhythm was seen during entire procedure. Patient was discharged and being managed on anti-anginal medications with Nitrates, Beta blocker, Aspirin and Statin. Patient will be followed up for next one year as per institutional study protocol.

Now here one question which needs to be addressed is what will the clinical implications of the FFR value which approaches to borderline (0.75-0.80) when there is reproduction of similar clinical angina during IC adenosine. Whether such lesion needs to be revascularized or not? Or whether we need to lower the threshold for revascularization of such lesions.

\section{Discussion}

Adenosine binds with 4 evolutionary well-conserved receptor subtypes that are ubiquitously expressed: A1, A2A, A2B, and A3 [2,3]. Activation of cardiac A1 receptors has a myocardial depressant effect with negative chronotropic and dromotropic effects, inhibition of Atrioventricular (AV) node conduction and prolongation of the refractory period [4] (Figure 1). 


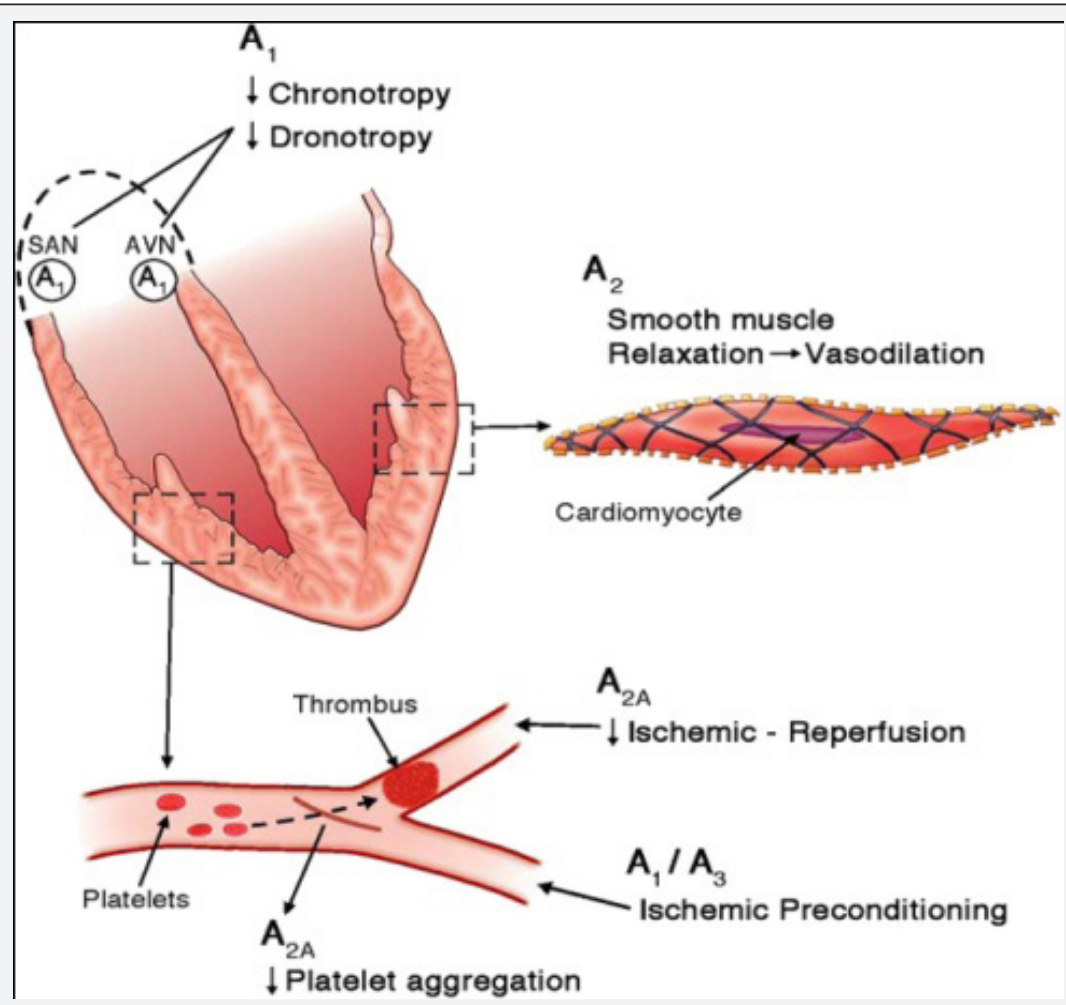

Figure 1: The Cardiovascular Effects of Adenosine.

Activation of $\mathrm{A} 2 \mathrm{~A}$ and $\mathrm{A} 2 \mathrm{~B}$ adenosine receptors produces potent vasodilation of most vascular beds including the coronary circulation, resulting in an increase in myocardial blood flow. A2B receptors are thought to produce mast cell degranulation and bronchial constriction [5]. A3 receptors are mainly peripherally located but are thought to play a role in mediating pre-conditioning. Adenosine causes a sensation of dyspnea in healthy patients but has not been shown to objectively produce bronchospasm. This dyspnogenic property has been proposed to be a result of direct stimulation of pulmonary C fibers by adenosine [6].

Intracoronary adenosine administration provokes chest pain similar to the angina at doses used for hyperemia testing. Aminophylline, an adenosine A1-receptor antagonist, significantly reduces the severity of both adenosine and exerciseinduced chest pain. These findings indicate that adenosine is a stimulus adequate to produce cardiac pain and could be partially responsible for the anginal pain during myocardial ischemia. This effect does not seem to be related to adenosine-induced coronary dilation (mediated mainly by $\mathrm{A} 2 \mathrm{a}$ and $\mathrm{A} 2 \mathrm{~b}$ receptors) and appears predominantly mediated by A1-receptor stimulation [7]. Typical angina pain during pharmacological vasodilator stress may reflect regional myocardial ischemia based on coronary steal. Chest pain may occur with patients with normal myocardial perfusion studies because of the involvement of adenosine A1 receptors in the nociceptive pathway influencing the sensation of chest pain [8]. The fact that the severity of chest pain provoked by intravenous adenosine is less in patients with silent ischemia, although difficult to interpret because of the systemic algogenic effects of this substance, further supports the hypothesis that adenosine may play an important role in the production of the anginal pain [8]. According to ACC/AHA/SCAI AUC for cardiac catheterisation, FFR measurements $<0.75$ are associated with ischemia on exercise testing and adjunct imaging (echo or nuclear) with high sensitivity (88\%), specificity (100\%), and overall accuracy (93\%). FFR measurements $>0.80$ are associated with negative ischemic results with a predictive accuracy of 95\% [9]. According to 2013 ESC guidelines on the management of stable coronary artery disease it's a class I B indication to revascularize the stenoses with FFR $<0.80$ in patients with angina symptoms or positive stress test [10]. In such lesions deferral of revascularization could still be safely considered.

\section{References}

1. Layland J, Carrick D, Lee M, Oldroyd K, Berry C (2014) Adenosine Physiology, Pharmacology, and Clinical Applications. JACC Cardiovasc Interv 7(6): 581-591.

2. Shryock JC, Belardinelli L (1997) Adenosine and adenosine receptors in the cardiovascular system: biochemistry, physiology, and pharmacology. Am J Cardiol 79(12A): 2-10.

3. Fredholm BB (2007) Adenosine, an endogenous distress signal, modulates tissue damage and repair. Cell Death Differ 14(7): 13151323.

4. Sato A, Terata K, Miura H, Toyama K, Loberiza FR Jr, et al. (2005) Mechanism of vasodilation to adenosine in coronary arterioles from patients with heart disease. Am J Physiol Heart Circ Physiol 288(4): H1633-1640.

5. Feoktistov I, Biaggioni I (1997) Adenosine A2B receptors. Pharmacol Rev 49(4): 381-402.

6. Burki NK, Dale WJ, Lee LY (2005) Intravenous adenosine and dyspnea in humans. J Appl Physiol 98(1): 180-185. 
7. Miller DD (2013) Physiologic and pharmacologic stressors ( $4^{\text {th }}$ Edn), In Atlas of Nuclear Cardiology, New York, Springer, pp 111-144.

8. Crea F, Pupita G, Galassi AR, el-Tamimi H, Kaski JC, et al. (1990) Role of Adenosine in Pathogenesis of Anginal Pain. Circulation 81(1): 164172

9. Windecker S, Kolh P, Alfonso F, Collet JP, Cremer J, et al. (2014) ESC/ EACTS Guidelines on myocardial revascularization The Task Force on Myocardial Revascularization of the European Society of Cardiology
(ESC) and the European Association for Cardio-Thoracic Surgery (EACTS). Developed with the special contribution of the European Association of Percutaneous Cardiovascular Interventions (EAPCI). Eur Heart J 35(37): 2541-2619.

10. Montalescot G, Sechtem U, Achenbach S, Andreotti F, Arden C, et al. (2013) ESC guidelines on the management of stable coronary artery disease: the Task Force on the management of stable coronary artery disease of the European Society of Cardiology. Eur Heart J 34(38): 2949-3003.

Your next submission with Juniper Publishers will reach you the below assets

- Quality Editorial service

- Swift Peer Review

- Reprints availability

- E-prints Service

- Manuscript Podcast for convenient understanding

- Global attainment for your research

- Manuscript accessibility in different formats

( Pdf, E-pub, Full Text, Audio)

- Unceasing customer service

Track the below URL for one-step submission https://juniperpublishers.com/online-submission.php 